\title{
On the ethics of not supplementing low 25- hydroxyvitamin D levels in a controlled study in relapsing remitting multiple sclerosis
}

Citation for published version (APA):

Smolders, J., Rolf, L., Damoiseaux, J., \& Hupperts, R. (2017). On the ethics of not supplementing low 25hydroxyvitamin $\mathrm{D}$ levels in a controlled study in relapsing remitting multiple sclerosis. Journal of the Neurological Sciences, 379, 331-331. https://doi.org/10.1016/j.jns.2017.06.009

Document status and date:

Published: 15/08/2017

DOI:

10.1016/j.jns.2017.06.009

Document Version:

Publisher's PDF, also known as Version of record

Document license:

Taverne

Please check the document version of this publication:

- A submitted manuscript is the version of the article upon submission and before peer-review. There can be important differences between the submitted version and the official published version of record.

People interested in the research are advised to contact the author for the final version of the publication, or visit the DOI to the publisher's website.

- The final author version and the galley proof are versions of the publication after peer review.

- The final published version features the final layout of the paper including the volume, issue and page numbers.

Link to publication

\footnotetext{
General rights rights.

- You may freely distribute the URL identifying the publication in the public portal. please follow below link for the End User Agreement:

www.umlib.nl/taverne-license

Take down policy

If you believe that this document breaches copyright please contact us at:

repository@maastrichtuniversity.nl

providing details and we will investigate your claim.
}

Copyright and moral rights for the publications made accessible in the public portal are retained by the authors and/or other copyright owners and it is a condition of accessing publications that users recognise and abide by the legal requirements associated with these

- Users may download and print one copy of any publication from the public portal for the purpose of private study or research.

- You may not further distribute the material or use it for any profit-making activity or commercial gain

If the publication is distributed under the terms of Article 25fa of the Dutch Copyright Act, indicated by the "Taverne" license above, 


\section{Letter to the Editor}

\section{On the ethics of not supplementing low 25-hydroxyvitamin D levels in a controlled study in relapsing remitting multiple sclerosis}

We thank Shukla et al. for their critical appraisal of our work. Regarding the first comment: we agree, as already mentioned in the manuscript, that our exploratory study has its limitations and did not reveal major new insights in the role vitamin $\mathrm{D}_{3}$ may have in the treatment of major depression in multiple sclerosis (MS). Regarding the ethical concerns of Shukla et al., we think there are some important nuances which make our study different from the study discussed by Lo and Grady [1].

First, all participants were treated with a first-line MS disease modifying treatment, Interferon Beta 1a. Second, participants were aware that they could be randomized in a high-dose vitamin $D_{3}$ arm for the duration of the trial. Risk-analyses provided confidence about safety, which was further supported by a recent study [2]. In the parental study, SOLAR, detailed safety analyses were performed and supervised by an independent data safety monitoring board, with individual dose-adjustments if toxicity was suspected (NCT01285401). Third, the risk of exposing participants to an adverse disease course of MS by not correcting low 25-hydroxyvitamin D (25(OH)D) levels is uncertain.

The association between 25(OH)D levels and MS outcomes may be driven by a disease modulating effect of vitamin $\mathrm{D}_{3}$ metabolites [3]. However, a progressing disease severity of MS induces sun-avoiding behavior [4]. Sunlight is not only the main source of vitamin $D_{3}$, but has also been argued to have direct disease-modulating effects independent from vitamin $\mathrm{D}_{3}$ [5]. Additionally, an activated immune system may lower 25(OH)D levels [6]. Although high 25(OH)D levels are associated with favorable MS outcomes in observational studies, it is uncertain whether vitamin $\mathrm{D}_{3}$ supplements improve these outcomes. From this perspective, it could even be argued to be unethical to advise patients vitamin $\mathrm{D}_{3}$ supplements with the goal of improving disease outcome. Furthermore, most efficacious 25(OH)D levels to aim for may be above the physiological range. To substantiate such advises, randomized controlled clinical studies with (high doses of ) vitamin $\mathrm{D}_{3}$ should reveal benefit for patients on targeted disease outcomes.

In the study discussed by Lo and Grady [1], a mild anemia was not disclosed to participants, which may hamper the diagnosis of underlying disease. In the case of vitamin $\mathrm{D}_{3}$, low $25(\mathrm{OH}) \mathrm{D}$ levels are frequently found in MS [7] as well as in the general population [4], and its etiology is unlikely to comprise alternative diseases. Patients have their physiological vitamin $\mathrm{D}_{3}$ exposure from diet and sunlight and were allowed to take $1.000 \mathrm{IU} / \mathrm{d}$ vitamin $\mathrm{D}_{3}$ supplements. As a result of participation in our study, they were actively informed about the possible implications of low 25(OH)D levels in MS.

Although we agree with Shukla et al. that our dataset failed to provide a clear answer to our patients on vitamin $\mathrm{D}_{3}$ supplementation and the endpoint depressive symptoms in MS, we think our data should encourage investigators to further address this issue. Whether supplementation of moderate or high amounts of vitamin $\mathrm{D}_{3}$ improves disease outcomes targeted by patients and clinicians should become clear from clinical trials. If a reproducible positive effect is identified, not supplementing MS patients with low 25(OH)D levels should be reconsidered.

\section{References}

[1] B. Lo, D. Grady, Addressing ethical lapses in research, JAMA Intern. Med. 177 (4) (2017) 461-462.

[2] S.M. Kimball, N. Mirhosseini, M.F. Holick, Evaluation of vitamin D3 intakes up to 15,000 international units/day and serum 25 -hydroxyvitamin D concentrations up to $300 \mathrm{nmol} / \mathrm{L}$ on calcium metabolism in a community setting, Dermatoendocrinology 9 (1) (2017) e1300213.

[3] J. Smolders, J. Damoiseaux, P. Menheere, R. Hupperts, Vitamin D as an immune modulator in multiple sclerosis, a review, J. Neuroimmunol. 194 (1-2) (2008) 7-17.

[4] I. van der Mei, A. Ponsonby, T. Dwyer, L. Blizzard, B.V. Taylor, T. Kilpatrick, H. Butzkueven, A.J. McMichael, Vitamin D levels in people with multiple sclerosis and community controls in Tasmania, Australia, J. Neurol. 254 (2007) 581-590.

[5] H.F. DeLuca, L. Plum, UVB radiation, vitamin D and multiple sclerosis, Photochem. Photobiol. Sci. 16 (3) (2017) 411-415.

[6] M.K. Holowaychuk, A.J. Birkenheuer, J. Li, H. Marr, A. Boll, S.K. Nordone, Hypocalcemia and hypovitaminosis D in dogs with induced endotoxemia, J. Vet. Intern. Med. 26 (2) (2012) 244-251.

[7] J. Smolders, P. Menheere, A. Kessels, J. Damoiseaux, R. Hupperts, Association of vitamin D metabolite levels with relapse rate and disability in multiple sclerosis, Mult. Scler. 14 (9) (2008) 1220-1224.

Joost Smolders

Academic MS Center Limburg, Zuyderland Medical Center, Sittard,

The Netherlands

Canisius Wilhelmina Hospital, Nijmegen, The Netherlands

Corresponding author at: Department of Neurology, Canisius

Wilhelmina Hospital, PO Box 9015, 6500 GS Nijmegen, The Netherlands.

E-mail address: j.smolders@cwz.nl.

Linda Rolf

Academic MS Center Limburg, Zuyderland Medical Center, Sittard,

The Netherlands

School for Mental Health and Neurocience,

Maastricht University Medical Center, Maastricht, The Netherlands

Jan Damoiseaux

Central Diagnostic Laboratory, Maastricht University Medical Center, Maastricht, The Netherlands

Raymond Hupperts

Academic MS Center Limburg, Zuyderland Medical Center, Sittard,

The Netherlands

School for Mental Health and Neurocience,

Maastricht University Medical Center, Maastricht, The Netherlands

7 June 2017 